\title{
VERIFIKASI PROGRAM PWR-FUEL DALAM MANAJEMEN BAHAN BAKAR PWR
}

\author{
Surian Pinem, Tagor M. Sembiring, Tukiran \\ Pusat Teknologi Keselamatan Reaktor Nuklir - BATAN \\ Email: pinem@batan.go.id \\ Diterima:19-07-2014 \\ Diterima dalam bentuk revisi: 14-08-2014 \\ Disetujui: 05-02-2015
}

\begin{abstract}
ABSTRAK
VERIFIKASI PROGRAM PWR-FUEL DALAM MANAJEMEN BAHAN BAKAR PWR. Majemen bahan bakar dalam teras PWR tidak mudah karena jumlah perangkat bahan bakar dalam teras sebanyak 192 perangkat sehingga banyak kemungkinan penempatan bahan bakar dalam teras. Konfigurasi perangkat bahan bakar dalam teras harus tepat dan akurat sehingga reaktor beroperasi aman dan ekonomis. Untuk itu perlu dilakukan verifikasi program PWRFUEL yang akan digunakan dalam manajemen bahan bakar PWR. Program PWR-FUEL didasarkan pada teori transport neutron dan diselesaikan dengan pendekatan metode difusi nodal banyak dimensi banyak kelompok dan metode difusi beda hingga (FDM). Tujuannya untuk memeriksa apakah program berfungsi dengan baik terutama untuk desain dan manajemen bahan bakar teras PWR. Verifikasi dilakukan dengan model pencarian teras setimbang pada tiga kondisi yaitu bebas boron, konsentrasi boron 1000 ppm dan konsentrasi boron kritis. Hasil perhitungan distribusi fraksi bakar rata-rata perangkat bahan bakar dan distribusi daya pada BOC dan EOC menunjukkan tren yang konsisten dimana perangkat bahan bakar dengan dengan daya yang tinggi pada BOC akan menghasilkan fraksi bakar yang tinggi pada EOC. Pada teras tanpa boron diperoleh faktor multiplikasi yang tinggi karena tidak adanya boron dalam teras dan efek produk fisi pada teras sekitar 3,8 \%. Efek reaktivitas larutan boron 1000 ppm pada BOC dan EOC masing-masing 6,44 \% dan 1,703 \%. Distribusi fluks neutron dan kerapatan daya menggunakan metode NODAL dan FDM mempunyai hasil yang sama. Hasil verifikasi menunjukkan bahwa program PWR-FUEL berfungsi dengan baik terutama untuk desain dan pengolahaan bahan bakar dalam teras PWR.
\end{abstract}

Kata kunci: manajemen bahan bakar, PWR, program PWR-FUEL

\section{ABSTRACT}

THE VERIFICATION OF PWR-FUEL CODE FOR PWR IN-CORE FUEL MANAGEMENT. In-core fuel management for PWR is not easy because of the number of fuel assemblies in the core as much as 192 assemblies so many possibilities for placement of the fuel in the core. Configuration of fuel assemblies in the core must be precise and accurate so that the reactor operates safely and economically. It is necessary for verification of PWR-FUEL code that will be used in-core fuel management for PWR. PWR-FUEL code based on neutron transport theory and solved with the approach of multi-dimensional nodal diffusion method many groups and diffusion finite difference method (FDM). The goal is to check whether the program works fine, especially for the design and in-core fuel management for PWR. Verification is done with equilibrium core search model at three conditions that boron free, 1000 ppm boron concentration and critical boron consentration. The result of the average burn up fuel assemblies distribution and power distribution at BOC and EOC showed a consistent trend where the fuel with high power at BOC will produce a high burn up in the EOC. On the core without boron is obtained a high multiplication factor because absence of boron in the core and the effect of fission products on the core around $3.8 \%$. Reactivity effect at $1000 \mathrm{ppm}$ boron solution of BOC and EOC is $6.44 \%$ and $1.703 \%$ respectively. Distribution neutron flux and power density using NODAL and FDM methods have the same result. The results show that the verification PWR-FUEL code work properly, especially for core design and in-core fuel management for PWR.

Keywords: in-core fuel management, PWR, PWR-FUEL code 
Jurnal Sains dan Teknologi Nuklir Indonesia

Indonesian Journal of Nuclear Science and Technology

Vol. 16, No 1, Februari 2015; 53-62

ISSN $1411-3481$

\section{PENDAHULUAN}

Salah satu hal yang penting dalam pemanfaatan energi nuklir adalah sistem keselamatan nuklir yang mendukung integritas PLTN agar aman selama operasi maupun saat terjadinya kecelakaan. Ketika PLTN akan dibangun dan dioperasikan, aspek yang sangat penting adalah terjaminnya keselamatan operasi reaktor yang ditunjukkan dengan dipenuhinya persyaratan keselamatan yang ditetapkan dalam desain. Manejemen bahan bakar dalam teras merupakan bagian penting dalam pengoperasian reaktor. Banyak metode yang telah digunakan dalam penyelesaian masalah manajemen bahan bakar dalam teras seperti Class-Based Search, teori perturbasi, Bat Algorithm(1,2,3), akan tetapi sampai saat ini penelitian masih terus berkembang untuk memperoleh suatu metode yang paling optimal.

Manajemen bahan bakar di PLTN / PWR agak rumit disebabkan karena parameter operasinya yang sangat luas / lebar modanya. Contohnya, variasi temperatur bahan bakar, kelongsong dan moderator/pendingin, variasi tekanan pendingin, pemakaian burnable poison dan racun dapat larut. Tetapi di lain pihak, yang menguntungkan adalah tujuannya hanya satu yaitu faktor ekonomi dan di dalam teras tidak ada benda lain selain elemen bakar. Untuk itu, harus dibuat pola pemuatan bahan bakar yang paling optimal untuk menghasilkan daya penuh dengan batas keselamatan yang cukup. Parameter keselamatan dalam manajemen bahan bakar teras PLTN dari aspek termohidraulika adalah faktor puncak daya aksial, reaktivitas lebih minimum, panjang siklus teras dan fraksi bakar maksimum yang diizinkan (4).

Strategi bahan bakar untuk mengendalikan distribusi daya dan energi yang dibangkitkan serta keselamatan operasi reaktor merupakan masalah yang sangat kompleks dalam operasi reaktor daya. Dalam reaktor air ringan, terdapat 150 sampai 700 perangkat bahan bakar, sehingga terdapat $10^{20}-10^{30}$ kemungkinan kombinasi susunan bahan bakar dalam teras reaktor.

Teras reaktor tersusun dari perangkat bahan bakar (fuel assembly) terdiri atas $17 \times$ 17 pin dengan panjang bahan bakar 4 meter dan diperkaya $\left({ }^{235} U\right)$ sekitar sekitar 2,35 4,45 \%. Untuk itu, diperlukan beberapa skema manajemen bahan bakar yang meliputi susunan bahan bakar, perhitungan teras dan keselamatan operasi serta meminimal penempatan bahan bakar dalam teras untuk memaksimalkan panjang siklus sehingga lebih ekonomis $(5,6)$.

Manajemen teras reaktor harus fokus pada penyesuaian beberapa parameter teras seperti koefesien temperatur moderator yang selalu harus negatif dalam semua kondisi operasi normal dan konsentrasi boron yang mungkin dibatasi oleh sistem (7). Selain itu batas shutdown tidak boleh melebihi harga minimum dan faktor puncak radial untuk bahan bakar harus di bawah batas keselamatan. Perhitungan harus dilakukan untuk berbagai kondisi operasi seperti cold zero power (CZP), hot zero power (HZP) dan hot full power (HZP) (8).. Untuk menjamin keselamatan operasi maka harga batas keselamatan untuk masing masing parameter keselamatan nuklir 
ditentukan melalui analisis fisika reaktor dalam semua kondisi operasi (9). Untuk itu, perlu dilakukan penelitian desain teras reaktor, untuk mengetahui hubungan batasan parameter keselamatan dan efesiensi ekonomi secara sistimatik.

Dalam penelitian ini digunakan program PWR - FUEL (10) yang menggunakan metode difusi nodal banyak dimensi dan metode difusi beda hingga (FDM). Untuk memperoleh hasil yang akurat sebelum dilakukan evaluasi manajemen teras PWR maka terlebih dahulu dilakukan verifikasi program yang digunakan. Verifikasi ini sangat penting karena perlu diketahuai apakah program dan fitur utamanya berfungsi dengan baik dalam perhitungan manajemen teras PWR.

Program PWR - FUEL merupakan manajemen bahan bakar teras PWR yang mensimulasikan operasi normal dari siklus awal (beginning of cycle, BOC) ke akhir siklus (end of cycle, EOC). Pada dasarnya program PWR - FUEL mempunyai tiga model perhitungan fraksi bakar yaitu perhitungan sederhana, pencarian teras setimbang dan transisi fraksi bakar teras. Pada perhitungan ini digunakan model pencarian teras setimbang dengan menggunakan kreteria konvergensi atau jumlah iterasi maksimum tercapai. Selama operasi normal perangkat bahan bakar dalam teras reaktor terbakar dalam kondisi kritis dengan mengontrol konsentrasi larutan boron dalam pendingin reaktor dari sistem pendingin primer.

\section{METODOLOGI}

Program PWR - FUEL menggunakan model pencarían teras setimbang dimana program secara otomatis mencari teras setimbang PWR. Untuk model ini harus ditentukan kelas fraksi bakar, pola pemasukan / pengeluaran bahan bakar dan panjang siklus teras yang paling optimal sehingga reaktor beroperasi dengan aman dan ekonomis. Tujuan penelitian ini untuk mengecek apakah program dan fitur utamanya berfungsi dengan baik terutama untuk parameter keselamatan desain dan pengelolaan bahan bakar teras PWR. Teras yang digunakan untuk verifikasi program PWR - FUEL adalah PWR generik dengan daya 1000 MWe. Teras penuh berisi 192 perangkat bahan bakar sehingga dalam perhitungan dilakukan $1 / 4$ teras sehingga hanya berisi 48 perangkat bahan bakar dengan lebar 0,2125 m.

Tampang lintang yang disediakan sebagai fungsi kondisi operasi yaitu cold zero power, hot zero power dan full power. Perhitungan sel bahan bakar dilakukan dengan paket program PIJ dalam SRAC2006 (11). Program akan menggenerasi konstanta kelompok yang disebut koefesien difusi $D$, tampang lintang serapan $\Sigma a$ dan tampang lintang produksi $v \Sigma f$ sebagai masukan dalam program PWR-FUEL. Seperti penjelasan sebelumnya paket program PWR - FUEL menggunakan metode difusi neutron 3-D dan banyak kelompok tenaga neutron dengan mengaplikasikan metode Nodal.

Gambar 1 menunjukkan rancangan riset yang dilakukan. Nilai desain yang dipakai sebagai acuan untuk evaluasi hasil perhitungan adalah faktor puncak daya, reaktivitas teras pada kondisi akhir siklus 
Jurnal Sains dan Teknologi Nuklir Indonesia

Indonesian Journal of Nuclear Science and Technology

Vol. 16, No 1, Februari 2015; 53-62

dan panjang siklus operasi. Besaran faktor puncak daya radial maksimum 1,48 , dengan

reaktivitas $k_{\text {eff }}$ mendekati 1,05 (reaktivitas lebih $5 \%$ ) pada EOC dengan panjang siklus semaksimal mungkin.

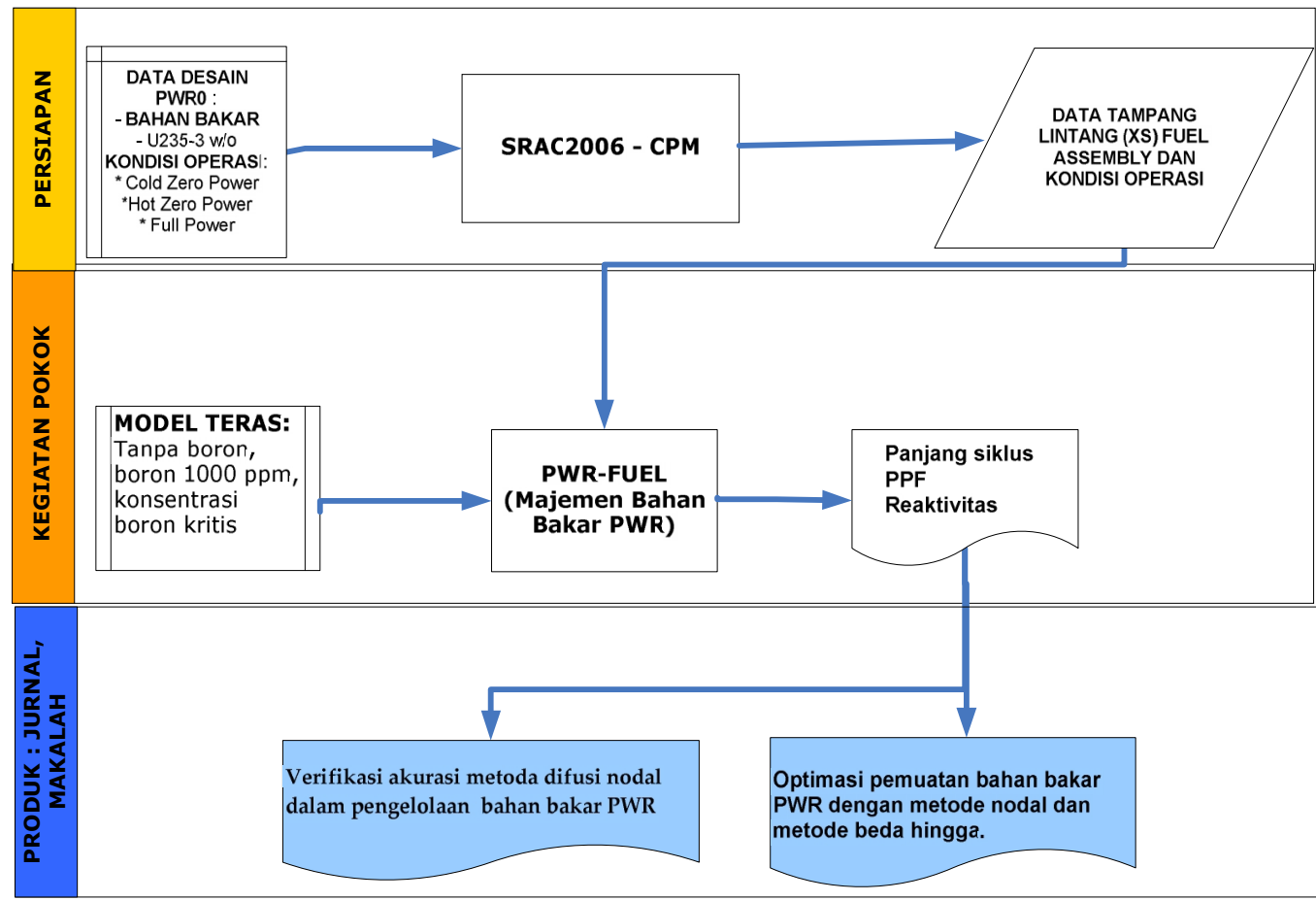

Gambar 1. Diagram alir perhitungan manajemen bahan bakar PWR

Berkaitan dengan kreteria numerik digunakan dalam perhitungan adalah kreteria konvergensi faktor multiplikasi efektif $\left(k_{\text {eff }}\right)$, kelompok fluks neutron dan daya rata-rata perangkat bahan bakar. Kreteria konvergensi $0,1 \%$ dan jumlah maksimum iterasi untuk mencapai teras setimbang ditetapkan 20.

Untuk mendapatkan teras setimbang dilakukan pada kondisi tanpa boron, boron 1000 ppm dan konsentrasi boron kritis yang diperoleh secara otomatis. Hal ini dilakukan untuk mengetahui efek produk fisi dan boron dalam teras karena dalam PWR biasanya digunakan konsenterasi boron kritis.

\section{HASIL DAN PEMBAHASAN}

Susunan perangkat bahan bakar, kelas fraksi bakar dan indentifikasi material dalam teras reaktor yang paling optimal disajikan dalam Gambar 2 sementara skema reload / reshuffling ditunjukkan dalam Gambar 3. Teras dibagi dalam tiga fraksi bakar dimana fraksi bakar pertama adalah bahan bakar segar, fraksi bakar kedua adalah pembakaran pertama dan fraksi bakar ke tiga adalah pembakaran ke dua. Pada BOC, perangkat bahan bakar dengan kelas fraksi bakar pertama adalah perangkat bahan bakar segar yang dimasukkan kedalam teras. Pada teras EOC, perangkat bahan bakar dengan fraksi bakar kelas ketiga yang harus dikeluarkan dari teras yang telah mengalami pembakaran ke tiga.

Pada kondisi BOC seperti ditunjukkan pada Gambar 2, bahan bakar pada posisi H- 
9 diisi bahan bakar FE-01 yang telah dibakar tiga kali, posisi G-9 diisi FE-02 yang telah dibakar dua kali dan posisi D-9 diisi FE-05 yang belum dibakar (bahan bakar segar). Setelah teras mengalami operasi satu siklus pada kondisi EOC seperti ditunjukkan pada Gambar 3 maka bahan bakar FE-01 menjadi bahan bakar kelas empat sehingga keluar dari teras dan FE-02 menjadi kelas ke tiga dan ditempatkan di posisi $\mathrm{H}-9$ serta $\mathrm{FE}-05$ menjadi bahan bakar kelas ke dua dan ditempatkan diposisi G-9. Bahan bakar yang lain dilakukan dengan aturan yang sama.

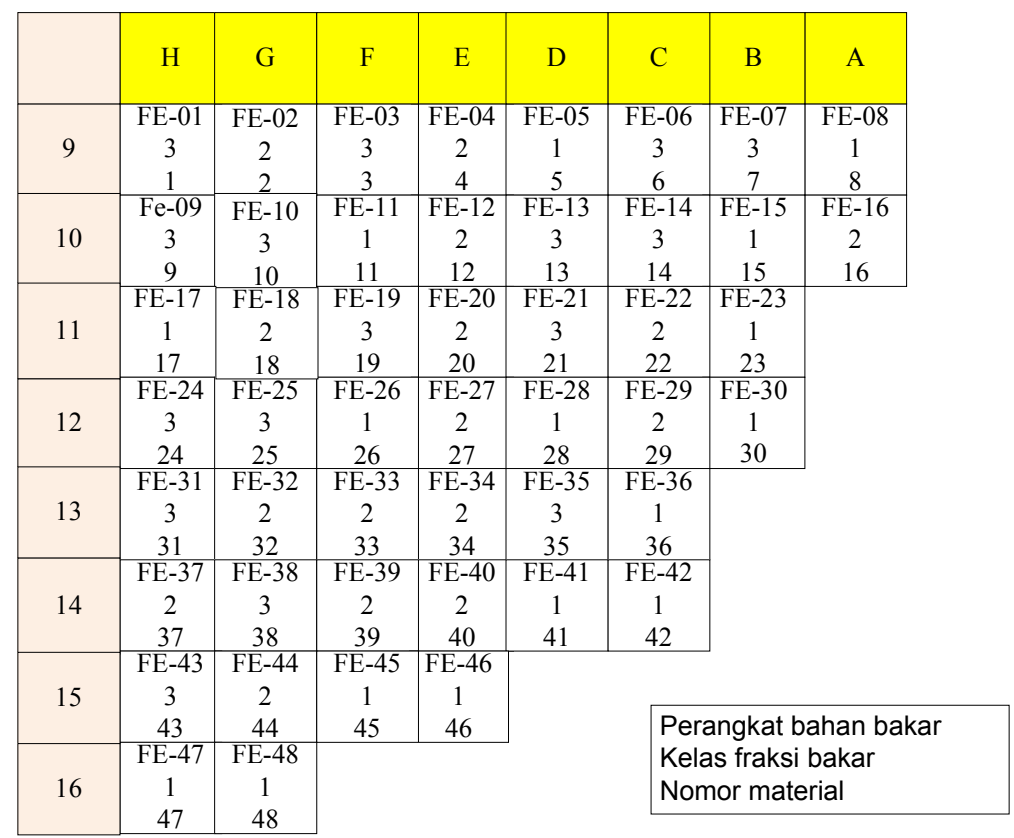

Gambar 2. Penyusunan perangkat bahan bakar pada kondisi BOC

\begin{tabular}{|c|c|c|c|c|c|c|c|c|}
\hline & $\mathrm{H}$ & G & $\mathrm{F}$ & E & $\mathrm{D}$ & C & B & A \\
\hline & FE-02 & FE-05 & FE-04 & FE-08 & FE-49 & FE-12 & FE-16 & FE-50 \\
\hline 9 & 3 & 2 & 3 & 2 & 1 & 3 & 3 & 1 \\
\hline & 2 & 5 & 4 & 8 & 49 & 12 & 16 & 50 \\
\hline & $\mathrm{Fe}-18$ & FE-20 & FE-51 & FE-11 & $\mathrm{FE}-22$ & FE-27 & FE-52 & FE-15 \\
\hline 10 & 3 & 3 & 1 & 2 & 3 & 3 & 1 & 2 \\
\hline & 18 & 20 & 51 & 11 & 22 & 27 & 52 & 15 \\
\hline & FE-53 & FE-17 & FE-29 & FE-22 & FE-32 & FE-23 & FE-54 & \\
\hline 11 & 1 & 2 & 3 & 2 & 3 & 2 & 1 & \\
\hline & 53 & 17 & 29 & 22 & 32 & 23 & 54 & \\
\hline & FE-34 & FE-38 & FE-55 & FE-28 & FE-56 & FE-30 & FE-57 & \\
\hline 12 & 3 & 3 & 1 & 2 & 1 & 2 & 1 & \\
\hline & 34 & 38 & 55 & 28 & 56 & 30 & 57 & \\
\hline & FE-39 & FE -36 & $\mathrm{FE}-41$ & FE-37 & $\mathrm{FE}-44$ & FE-58 & & \\
\hline 13 & 3 & 2 & 2 & 2 & 3 & 1 & & \\
\hline & 39 & 36 & 41 & 37 & 44 & 58 & & \\
\hline & FE-48 & FE-26 & $\mathrm{FE}-42$ & FE-45 & FE- 60 & FE-61 & & \\
\hline 14 & 2 & 3 & 2 & 2 & 1 & 1 & & \\
\hline & 48 & 26 & 42 & 45 & 60 & 61 & & \\
\hline & $\mathrm{FE}-37$ & $\mathrm{FE}-46$ & $\mathrm{FE}-62$ & $\mathrm{FE}-63$ & & & & \\
\hline 15 & 3 & 2 & 1 & 1 & & & & \\
\hline & 37 & 46 & 62 & 63 & & \multirow{2}{*}{\multicolumn{3}{|c|}{$\begin{array}{l}\text { Perangkat bahan bakar } \\
\text { Kelas fraksi bakar } \\
\text { Nomor material }\end{array}$}} \\
\hline 16 & $\begin{array}{c}\text { FE }-59 \\
1\end{array}$ & $\begin{array}{c}\text { FE- } 64 \\
1\end{array}$ & & & & & & \\
\hline
\end{tabular}

Gambar 3. Reload/reshuffling perangkat bahan bakar 


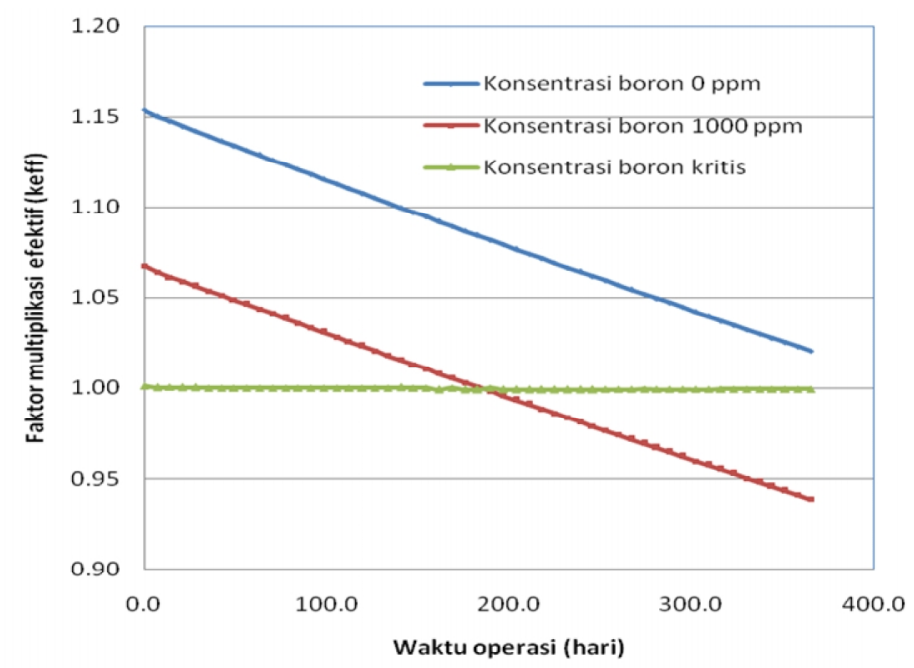

Gambar 4. Perubahan $\mathrm{k}_{\text {eff }}$ sebagai fungsi waktu operasi reaktor

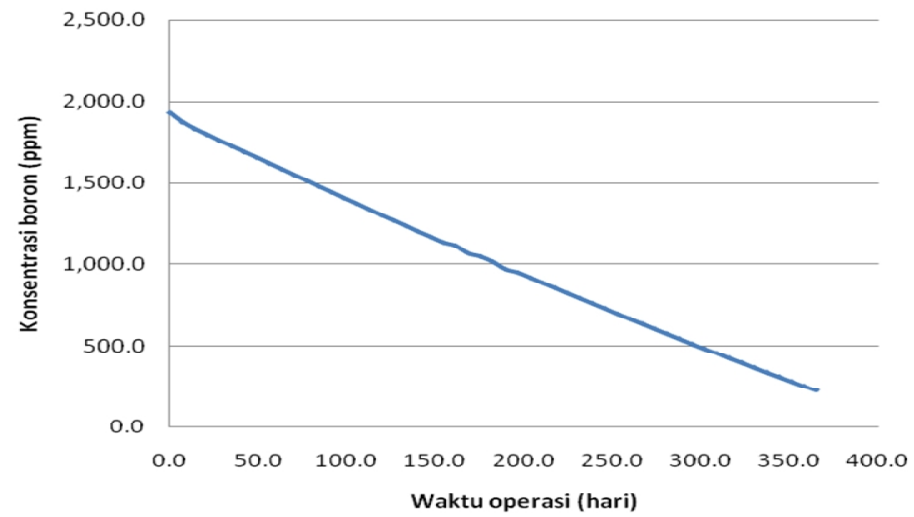

Gambar 5. Konsentrasi boron sebagai fungsi operasi reaktor pada kondisi konsentrasi boron kritis

Hasil perhitungan $\mathrm{k}_{\text {eff }}$ terhadap waktu operasi reaktor terlihat pada Gambar 4 dimana harga $k_{\text {eff }}$ untuk teras tanpa boron terlalu tinggi dan tidak realistik karena tidak adanya larutan boron dalam pendingin reaktor. Untuk kondisi operasi dimana konsentrasi boron dipertahankan pada konsentasi 1000 ppm maka pada EOC reaktor tidak kritis lagi disebabkan konsentrasi boron terlalu kecil. Hasil $k_{\text {eff }}$ pada keadaan BOC dan EOC reaktor tetap pada kondisi kritis untuk kondisi konsentrasi boron kritis.

Gambar 5 menunjukkan konsentrasi boron kritis sebagai fungsi waktu operasi. Konsentrasi boron pada awal kritis masih cukup tinggi karena dalam perhitungan ini menggunakan bahan bakar tanpa pirex dan IFBA sehingga reaktivitas cukup besar.

Daftar heavy metal, fraksi bakar dan $\mathrm{k}_{\text {eff }}$ bebas boron ditunjukkan dalam Tabel 1 . Fraksi bakar rata - rata teras pada kondisi BOC dan EOC masing-masing 1,3282E+04 dan 2,4558E+04 MWd/t. Efek reaktivitas hasil produksi fisi seperti $\mathrm{Xe}-135$ dan Sm149 sekitar 3,9 \% pada kondisi BOC dan $3,8 \%$ pada kondisi EOC.

Heavy metal inventory, fraksi bakar dan $k_{\text {eff }}$ dengan konsenterasi boron 1000 ppm ditunjukkan dalam Tabel 2. Karaktristik fraksi bakar dan heavy metal inventory yang ditunjukkan pada Tabel 2 sama dengan 
Tabel 1. Sementara itu, efek konsentarsi boron 1000 ppm pada BOC dan EOC masing-masing 10,34 \% dan 5,5\%.

Heavy metal inventory, fraksi bakar dan $k_{\text {eff }}$ dengan konsenterasi boron kritis ditunjukkan dalam Tabel 3. Karaktristik fraksi bakar dan heavy metal inventory yang ditunjukkan pada Tabel 3 sama dengan Tabel 1 dan 2. Hasil ini menunjukkan bahwa hasil yang diperoleh baik karena heavy metal inventory tidak akan berpengaruh dengan konsentrasi boron dalam pendingin reaktor.

Program PWR-FUEL menggunakan motode Nodal dan sebagai pembanding digunakan metode beda hingga (FDM) sehingga diketahui keakuratan hasil perhitungan.

Tabel 1. Heavy metal inventory dan karaktistik fraksi bakar teras tanpa boron

\begin{tabular}{lcc}
\hline \multicolumn{1}{c}{ Inventory (1/4 teras) $(\mathrm{kg})$} & BOC & EOC \\
\hline U-235 & $4,4723 \mathrm{E}+02$ & $2,4607 \mathrm{E}+02$ \\
$\mathrm{U}-236$ & $4,5947 \mathrm{E}+01$ & $7,7450 \mathrm{E}+01$ \\
$\mathrm{U}-238$ & $2,3365 \mathrm{E}+04$ & $2,3184 \mathrm{E}+04$ \\
$\mathrm{PU}-239$ & $6,7812 \mathrm{E}+01$ & $1,0608 \mathrm{E}+02$ \\
$\mathrm{PU}-240$ & $1,7680 \mathrm{E}+01$ & $3,3379 \mathrm{E}+01$ \\
$\mathrm{PU}-241$ & $8,6709 \mathrm{E}+00$ & $1,6849 \mathrm{E}+01$ \\
$\mathrm{PU}-242$ & $2,2447 \mathrm{E}+00$ & $6,0443 \mathrm{E}+00$ \\
$\mathrm{NP}-237$ & $2,8019 \mathrm{E}+00$ & $5,5328 \mathrm{E}+00$ \\
$\mathrm{NP}-239$ & $1,3919 \mathrm{E}+00$ & $2,2383 \mathrm{E}+00$ \\
AM-241 & $1,4919 \mathrm{E}-01$ & $3,3190 \mathrm{E}-01$ \\
AM-243 & $2,4299 \mathrm{E}-01$ & $8,3810 \mathrm{E}-01$ \\
XE-135 & $4,3584 \mathrm{E}-03$ & $3,5161 \mathrm{E}-03$ \\
SM-149 & $2,9591 \mathrm{E}-02$ & $2,4173 \mathrm{E}-02$ \\
Total Uranium dalam teras $(\mathrm{kg})$ & $2,3858 \mathrm{E}+04$ & $2,3508 \mathrm{E}+04$ \\
Total Plutonium dalam teras $(\mathrm{kg})$ & $9,6407 \mathrm{E}+01$ & $1,6236 \mathrm{E}+02$ \\
Fraksi bakar rata-rata (MWD/t) & $1,3282 \mathrm{E}+04$ & $2,4558 \mathrm{E}+04$ \\
Fraksi bakar rata-rata (\% hilang U-235) & $3,8627 \mathrm{E}+01$ & $6,6233 \mathrm{E}+01$ \\
keff $(\mathrm{HZP}$, Xe, Sm, bebas boron) & 1,153900000 & 1,020500000 \\
keff $(\mathrm{HZP}$, bebas Xe, Sm, boron) & 1,208200000 & 1,061600000 \\
Efek reaktivitas (\%) & 3,9000 & 3,8000 \\
\hline
\end{tabular}

Tabel 2. Daftar heavy metal dan karaktistik fraksi bakar teras boron $1000 \mathrm{ppm}$

\begin{tabular}{|c|c|c|}
\hline Inventory (1/4 teras) $(\mathrm{kg})$ & $\mathrm{BOC}$ & EOC \\
\hline U-235 & $4,4444 \mathrm{E}+02$ & $2,4327 E+02$ \\
\hline $\mathrm{U}-236$ & $4,6379 E+01$ & $7,7882 E+01$ \\
\hline$U-238$ & $2,3363 E+04$ & $2,3182 E+04$ \\
\hline PU-239 & $6,8218 E+01$ & $1,0649 \mathrm{E}+02$ \\
\hline PU-240 & $1,7940 E+01$ & $3,3641 \mathrm{E}+01$ \\
\hline PU-241 & $8,8220 E+00$ & $1,7001 \mathrm{E}+01$ \\
\hline PU-242 & $2,2986 E+00$ & $6,0981 E+00$ \\
\hline NP-237 & $2,8454 \mathrm{E}+00$ & $5,5765 \mathrm{E}+00$ \\
\hline NP-239 & $1,3970 \mathrm{E}+00$ & $2,2435 E+00$ \\
\hline AM-241 & $1,5237 \mathrm{E}-01$ & $3,3513 \mathrm{E}-01$ \\
\hline AM-243 & $2,4977 \mathrm{E}-01$ & $8,4462 E-01$ \\
\hline XE-135 & $4,3453 \mathrm{E}-03$ & 3,5029E-03 \\
\hline SM-149 & 2,9506E-02 & $2,4088 \mathrm{E}-02$ \\
\hline Total Uranium dalam teras $(\mathrm{kg})$ & $2,3854 \mathrm{E}+04$ & $2,3503 E+04$ \\
\hline Total Plutonium dalam teras $(\mathrm{kg})$ & $9,7278 E+01$ & $1,6323 \mathrm{E}+02$ \\
\hline Fraksi bakar rata-rata (MWD/t) & $1,3445 E+04$ & $2,4720 \mathrm{E}+04$ \\
\hline Fraksi bakar rata-rata (\% hilang U-235) & $3,9010 \mathrm{E}+01$ & $6,6616 \mathrm{E}+01$ \\
\hline $\mathrm{k}_{\text {eff }}(\mathrm{HZP}, \mathrm{Xe}, \mathrm{Sm}$, boron) & 1,067800000 & 0,938700000 \\
\hline $\mathrm{k}_{\mathrm{eff}}(\mathrm{HZP}$, bebas $\mathrm{Xe}, \mathrm{Sm}$, boron) & 1,206000000 & 1,059700000 \\
\hline Efek reaktivitas (\%) & 10,3400 & 5,5030 \\
\hline
\end{tabular}


Jurnal Sains dan Teknologi Nuklir Indonesia

Indonesian Journal of Nuclear Science and Technology

Vol. 16, No 1, Februari 2015; 53-62

Tabel 3. Heavy metal inventory dan karaktistik fraksi bakar teras konsentrasi boron kritis

\begin{tabular}{ccc}
\hline Inventory $(1 / 4$ teras $)(\mathrm{kg})$ & BOC & EOC \\
\hline U-235 & $4,4499 \mathrm{E}+02$ & $2,4381 \mathrm{E}+02$ \\
$\mathrm{U}-236$ & $4,6294 \mathrm{E}+01$ & $7,7798 \mathrm{E}+01$ \\
$\mathrm{PU}-239$ & $2,3363 \mathrm{E}+04$ & $2,3182 \mathrm{E}+04$ \\
$\mathrm{PU}-240$ & $6,8136 \mathrm{E}+01$ & $1,0641 \mathrm{E}+02$ \\
$\mathrm{PU}-241$ & $1,7889 \mathrm{E}+01$ & $3,3591 \mathrm{E}+01$ \\
$\mathrm{PU}-242$ & $8,7929 \mathrm{E}+00$ & $1,6973 \mathrm{E}+01$ \\
$\mathrm{NP}-237$ & $2,2878 \mathrm{E}+00$ & $6,0869 \mathrm{E}+00$ \\
$\mathrm{NP}-239$ & $2,8369 \mathrm{E}+00$ & $5,5680 \mathrm{E}+00$ \\
$\mathrm{AM}-241$ & $1,3960 \mathrm{E}+00$ & $2,2424 \mathrm{E}+00$ \\
AM-243 & $1,5177 \mathrm{E}-01$ & $3,3455 \mathrm{E}-01$ \\
XE-135 & $2,4832 \mathrm{E}-01$ & $8,4295 \mathrm{E}-01$ \\
SM-149 & $4,3478 \mathrm{E}-03$ & $3,5055 \mathrm{E}-03$ \\
Total Uranium dalam teras $(\mathrm{kg})$ & $2,9523 \mathrm{E}-02$ & $2,4104 \mathrm{E}-02$ \\
Total Plutonium dalam teras $(\mathrm{kg})$ & $2,3854 \mathrm{E}+04$ & $2,3504 \mathrm{E}+04$ \\
Fraksi bakar rata-rata (MWD/t) & $9,7106 \mathrm{E}+01$ & $1,6306 \mathrm{E}+02$ \\
Fraksi bakar rata-rata $(\%$ hilang U-235) & $1,3412 \mathrm{E}+04$ & $2,4688 \mathrm{E}+04$ \\
Keff (HZP, Xe, Sm, boron) & $3,8934 \mathrm{E}+01$ & $6,6542 \mathrm{E}+01$ \\
keff $($ HZP, bebas Xe, Sm, boron) & 1,00110000 & 0,99970000 \\
Efek reaktivitas (\%) & 1,20660000 & 1,06010000 \\
\hline
\end{tabular}

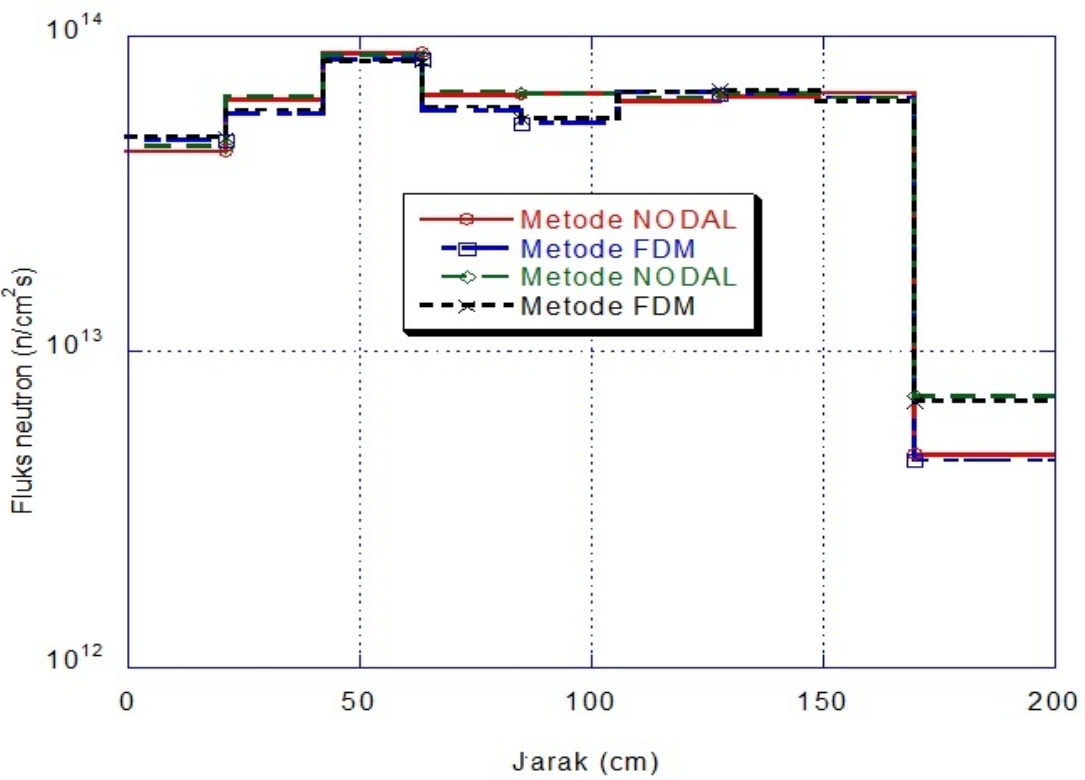

Gambar 6. Distribusi fluks neutron pada teras konsentrasi boron kritis

Untuk mengetahui apakah kedua metode dapat digunakan dalam perhitungan manajemen bahan bakar dalam teras maka dilakukan perhitungan fluks neutron dan kerapatan daya. Fluks neutron dihitung dengan 2 kelompok energi neutron. Hasil perhitungan fluks neutron dan kerapatan daya ditunjukkan dalam Gambar 6 dan 7.
Harga kerapatan daya rata-rata sebesar $93,57 \mathrm{~W} / \mathrm{cm}^{3}$, dimana harga ini masih dibawah PWR sebesar 109,7 W/cm ${ }^{3}$ [12]. Dari hasil tersebut terlihat bahwa kedua metode tidak ada perbedaan yang signifikan. Hal ini menunjukkan bahwa kedua metode dapat digunakan dalam pengolahan bahan bakar dalam teras 


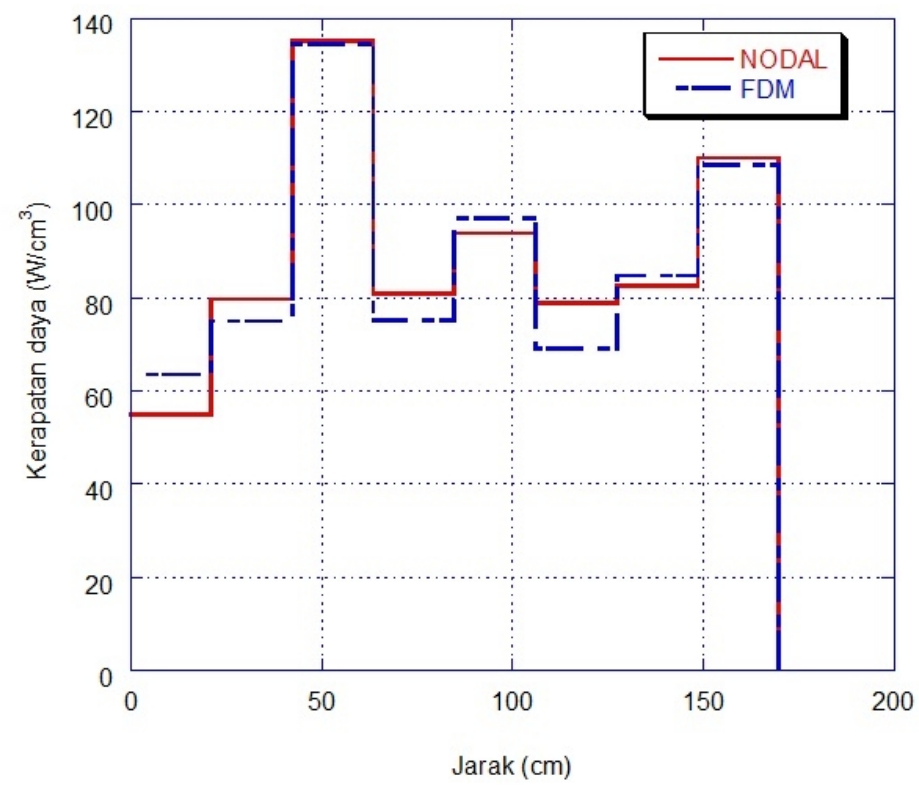

Gambar 7. Kerapatan daya pada teras konsentrasi boron kritis

\section{KESIMPULAN}

Hasil perhitungan $\mathrm{k}_{\text {eff }}$ menunjukan ada perbedaan antara teras tanpa boron, boron tetap dan konsentrasi boron kritis sehingga program dapat menentukan efek produk fisi dan konsentarsi boron dalam teras. Karaktristik fraksi bakar dan heavy metal inventory mempunyai hasil yang sama untuk teras tanpa boron, boron tetap dan konsentrasi boron kritis menunjukkan bahwa program berjalan dengan baik. Berdasarkan hasil $k_{\text {eff, }}$ faktor puncak daya, karaktristik fraksi bakar dan konfigurasi teras setimbang menunjukkan bahwa program PWR - FUEL dapat digunakan dalam perhitungan desain teras dan manajemen bahan bakar teras PWR. Program juga dapat menggunakan dua metode yaitu metode nodal dan FDM. Selanjutnya program ini akan digunakan untuk benchmarking teras PWR dan perhitungan manajemen bahan bakar teras PWR AP1000.

\section{DAFTAR PUSTAKA}

1. Anderson Alvarenga De Moura Meneses, Paola Rancoita, Roberto Schirru, Luca Maria Gambardella. A class-based search for the in-core fuel management optimization of a Pressurized Water Reactor. Annals of Nuclear Energy. 2010; 37: 1554 - 1560.

2. Mohammad Hosseini, Naser Vosoughi. Development of a VVER-1000 core loading pattern optimization program based on perturbation theory. Annals of Nuclear Energy. 2012; 39: 35-4.

3. S. Kashi, A. Minuchehr, N. Poursalehi, A. Zolfaghari. Bat algorithm for the fuel arrangement optimization of reactor core. Annals of Nuclear Energy. 2014; 64: 144-151

4. Paul J, Turinsky, at al. Evolution of nuclear fuel management and reactor operational aid tools. Nuclear Engineering and Technology. 2005; 37: 79-90 
5. G, Espinosa-Paredes, Juan R, Guzmán. Reactor physics analysis for the design of nuclear fuel lattices with burnable poisons. Nuclear Engineering and Design. 2011; 241: 5039-5054.

6. Shichang Liu, Jiejin Cai. Studies of fuel loading pattern optimization for a typical pressurized water reactor (PWR) using improved pivot particle swarm method. Annals of Nuclear Energy. 2012; 50: 117-125.

7. F. Faghihi, A.H. Fadaie, R. Sayareh. Reactivity coefficients simulation of the Iranian VVER-1000 nuclear reactor using WIMS and CITATION codes. Progress in Nuclear Energy. 2007; 49 : 68 -79..

8. M, Rafiei Karahroudi, S,A, Mousavi Shirazi , K. Sepanloo. Optimization of designing the core fuel loading pattern in a VVER-1000 nuclear power reactor using the genetic algorithm. Annals of Nuclear Energy. 2013; 57:142-150.

9. David Jalu, Gert Van Den Eynde, Stefan Vandewalle. Development of a core management tool for MYRRHA. Energy Conversion and Management. 2013;74: 562-568.

10.PWR-FUEL: In-Core fuel management code, version 2.0. User manual; 2012.

11.Okumura, K. et.al. SRAC 2006: A Comprehensive Neutronics Calculation Code System; 2006.

12. Syeilendra Pramuditya, Minoru Takahashi. Core design study for power uprating of integral primary system PWR. Annals of Nuclear Energy. 2013; 59: $16-24$ 